\title{
Broadening mass communication research for enhanced media practice
}

\author{
Fred A. Amadi
}

\begin{abstract}
This article examines how the attention which media scholarship gives to only the quantitative research method impacts on journalism practice in Nigeria. Firstly, typical mass media texts were purposively selected and presented on a titled table. Secondly Critical Discourse Analysis (CDA) methods were used to analyse selected texts. Thirdly e-mailing and audio recording were used to elicit comments from a reporter and an editor. The editor and the reporter who commented wrote the stories from which the selected newspaper texts were drawn. Lastly, elicited comments were used to buttress arguments as the analysis progressed. In Nigeria journalists report news without imputation. Reporting news without imputations flaws news presentation. In this article flaws in news presentation are attributed to the attention which media scholarship in Nigeria gives to only the quantitative research method. The article proposes that as the qualitative research method, more so than the quantitative method, imparts better critical skills to journalists, the qualitative method should be emphasised more in mass media research.
\end{abstract}

Key words: broadening, enhanced mass communication research, media practice.

\section{Introduction}

In Africa, there is a serious challenge to any proposition seeking to broaden the method of conducting mass communication research. This challenge is rooted in the belief among many communication scholars that the dominant quantitative approach is beyond reproach. At every level of mass communication scholarship in Nigeria, the quantitative research method holds significant importance. This degree of importance increases at the $\mathrm{PhD}$ level. At this level, a $\mathrm{PhD}$ research proposal is discredited if a candidate fails to 
include variables in the topic that are statistically measurable. This paper pursues the view that, in Africa, communication scholars might reconsider this restrictive stance about mass communication research/scholarship when they become familiar with the events that influenced stages in the development of mass communication and its research traditions.

It is generally believed that the formal study of mass communication at university level has had a chequered history. Swanson (2011) and Dennis (1989) report that between 1865 and 1870, when General Robert Lee was the president of Washington College, the general wrote to the college board of trustees asking for the establishment of 50 scholarships for young men intending to pursue a career in printing and journalism. According to Swanson, by 1875, five years after Lee's death, Cornell University had, following in Lee's footsteps, proposed a journalism programme in the university.

But it was the University of Missouri which later became the first university to give journalism the status of a university programme, starting instruction in journalism by 1878 (Swanson, 2011). Swanson's report provides a premise that scholars draw on when they disagree that France's École Supérieure de Journalisme, which was founded in 1899 (Wikipedia.Org), was not the first institution that offered a degree programme in journalism. Despite the pioneering spirit of General Robert Lee of Washington College and the trail-blazing effort by the University of Missouri, many American universities did not show much enthusiasm towards the study of journalism in the last decades of the $19^{\text {th }}$ century (Dennis, 1989). The first component of mass communication to suffer a negative influence as a result of the delay in the formal study of mass communication at university level was advertising and the research tradition that it inspired.

\section{Advertising industry and mass media research}

When advertising agencies in the early 1880s started making claims of "appeals to the rationality of science" and referring to what they were doing as "consumption engineering" (Mayhew, 1997: 197), they may not have envisaged that those claims were laying a precedent which would be copied to the detriment of broad-based mass communication research. The claims of "practical knowledge" and "applied scientific reasoning" (Mayhew, 1997: 197) by the advertising industry were spawned by a market survey research which the advertising firm of Ayer \& Sons carried out in 1879 for a 
manufacturer of threshing equipment (Mayhew, 1997). When the advertising firm of Ayer $\&$ Sons succeeded in predicting the volume of grain that would be produced on a countyby-county basis in the United States, the successful prediction gave the advertising industry and the survey research approach an enviable prestige in those early days when journalism as an academic discipline was in its infancy. The enviable prestige sparked competition. The competition reached a point where many American universities, at the turn of the 20th century, started offering courses in advertising and marketing. Following this new-found honour, the survey approach in research became an exemplary method of conducting media research. The influence of the survey approach to media research received a boost when George Gallup of the Gallup Poll fame wrote his doctoral dissertation in 1928 titled, "A New Technique for Measuring Reader Interest in Newspapers (Mayhew, 1997:199).

Gallup's well-paid consultancy services to media companies and his often accurate predictions about the audience, including his successful challenge of Reader's Digest's prediction about who would win the 1936 presidential election in the United States, gave a domineering boost to George Gallup and his media research method. Cementing these developments was the uncertainty that had gripped the founding fathers of the social sciences, at the turn of the twentieth century, regarding the best method of conducting social science research.

\section{The quantitative/qualitative divide in social science inquiry}

Towards the last years of the 19th century, influential scholars of the social sciences such as Emile Durkheim, Max Weber, Talcott Parsons, Carl Popper, Herbert Blumer, and others had contemplated the appropriateness of either the quantitative or the qualitative approach for social science research (Tucker, 1998; Ritzer, 2000). At the centre of the quantitative approach is the idea that social life could best be understood in terms of causal relationship between clearly defined, measurable variables. Contrarily, at the centre of the qualitative approach is the belief that social life would be better understood by an in-depth examination of a particular situation through the study of the processes by which people develop meaning in their lives (Seganti, 2010, Silverman \& Marvasti, 2008; Creswell, 2007; Silverman, 2006; Pryczak \& Bruce, 2005; Lindlof \& Taylor, 2002; Ang, 2001; Keyton, 2001; Tucker, 1998; Maxwell, 1996 \& Reinard, 1994). 
Despite these differing views, records show that before the quantitative research method gained a footing on a global scale, the qualitative approach had been considered the most appropriate method for studying human behaviour and for describing, explaining, and understanding social phenomena (Gobo, 2005; Lanigan, 1988). Mass communication programmes in African universities, but more so those in Nigeria, are yet to come to terms with the resurgence of the qualitative method. Mass communication programmes in Nigerian universities betray their lack of awareness of the qualitative method when they insist that validity in mass communication research is guaranteed only when the method is numerically-oriented (Ajala, 1996). For instance, when vacancies for research positions were advertised recently on the website of the National Open University of Nigeria (2009), preferential emphasis was made for candidates with quantitative skills.

For the avoidance of doubt, the point here is not to condemn the quantitative method of pursuing mass media research. Rather, the point is to correct a situation in Nigeria where nothing is said about the qualitative research method in research course-contents of mass communication departments. This systematic discouragement of the qualitative method in Nigeria restrains mass communication scholarship in the same manner in which unscrupulous embrace of the quantitative method is undermining research skills in the education discipline. Okeke \& Ume (2004) did, for instance, a study that targeted the assessment of the state of the art in relation to the methodological skills for research in the faculty of education in five first-generation Nigerian universities. After reviewing $20 \mathrm{PhD}$ dissertations, Okeke \& Ume found that the struggle to manipulate the independent variable in many of the dissertations forced the dissertations to look too contrived and artificial. According to Okeke \& Ume, these flaws emerged because of attempts by the authors of the dissertations to force complex psycho-social phenomena into quantification and aggregation in contexts not amenable to such.

Similarly, a cautious note sounded by Branston \& Stafford (2006) to those who overdramatise the effectiveness of quantitative content analysis in mass media research might be instructive here. According to them, research findings based solely on counting how many times the mass media interviewed parties in a conflict might not be a reliable means of determining which party in the conflict the media had favoured. Their view is that it 
might be wrong to assume that the side that got a higher frequency of coverage had, by virtue of that, enjoyed better media coverage. Branston \& Stafford state that when a party in a conflict receives a high interview frequency in a context where belligerent questioning was used, any advantage gained by the high interview frequency has been compromised. The inherent lesson here is that when a content analysis method emphasises only frequency count at the expense of a critical study of the structure and tone of questioning in a scenario like the one raised above by Branston \& Stafford, the outcome of such a study cannot be valid. Often quantitative content analysis, because of its failure to reckon with the structure, meaning, and tone of utterances, falls prey to this oversight. Such oversights are not lost on scholars. In fact, there is this view that "the hard data which quantitative researchers claim to provide can turn out to be a mirage" (Silverman, 2006: 42).

\section{Journalists, journalism and quantitative research/scholarship}

The cursory reading of certain remarks may give the impression that the way journalism is practiced today is beyond reproach. Among such remarks is, "journalists are detached observers. They separate themselves from the reality reported" (Reese, 1997: 424). Another remark is "in our lifetime we have become very powerful" (Rosen, 1999: 70). Upbeat as these remarks sound, they can hardly neutralise concerns expressed by scholars against the inability of journalism to rise beyond the flaws that undermine it.

Schiller (1996: 175), for instance, had condemned pretentious invocation of ethos of neutrality and objectivity by journalists when he observed that wherever one looks in the social sphere, one hears neutrality and objectivity being invoked to describe the "functioning of value-laden and purposeful activities which lend support to the prevailing institutional system". In practice, pretentious objectivity is used to set a uniform professional standard of ethics in a manner that had prompted Birkhead to argue that such "standard of ethics does not exist in fact and ought not exist in principle" (1991:229). In Eliasoph's view, the invocation of objectivity by journalists is partial and inadequate because such invocation forces journalists to work with a "frame of objectivity that precedes reason and unavoidably shapes the output of the journalists in an unreasonable way" (1997: 230). Contents produced under these unreasonable circumstances are the ones frowned against in Carew's "ritual view of communication” (1996: 233). 
The charge that the ritual view of communication brings against the mass media is that the news the mass media disseminate is not much useful as a process that helps people learn new things as it is just a mere ritual that is more preoccupied with portraying and confirming particular views of reality/the world. Fiske condemns journalistic output under this ritual mode as the "kind that does not help the masses contest domination" because of its failure to allow the subordinated to articulate "perceived flaws and contradictions inherent in the practices and discourses of the powerful" (2004: 219).

Fairclough raises the points of the "power behind social order of discourse" and "hidden effect of power" (2001: 46). Fairclough explains hidden effect of power as the culprit which, through the tacit enforcement of the power behind social order of discourse, unwittingly cajoles journalists into producing texts that manifest other meanings than those intended by journalists. Furthermore, Birkhead describes the power behind social order of discourse as being responsible for ensuring that media contents are structured with formulae to produce "formulaic stories" (1991: 228). He states that the embrace of formulae or moulds by journalists as they prepare news stories is not as a result of the soundness or authenticity of such method but borne out of a need to ensure maximisation of efficiency in the challenges of news production. This unconscionable pursuit of efficiency at the expense of clarity and logic in the operation of the mass media is decried as "distortion methodized" (Birkhead, 1991: 228); "a myth whose function is to bless the mess" (Griffin, 2000: 329); and "simulated egalitarianism” (Fairclough, 2001: 30).

There are also concerns about shoddy performances by the media in Nigeria. For instance, Udoakah has observed that "the Nigerian mass media no longer watch the ruling elites for the masses but the masses for the ruling elites" (1993:.92). Tinubu, (2005) observes that the credibility and effectiveness of the media in Nigeria have been gravely undermined by widespread corruption. Olumhense (2005) identifies ignorance as one factor responsible for making Nigerian newspapers appear among the ones with the shallowest memory in the history of journalism. The charge of shallowness and ignorance against Nigerian journalism resonates with Herbert Gans who, as cited in Kunczik, (1995), had carried out a study which concluded that in discharging their duty, journalists are hampered by ignorance and shallow knowledge. 
Journalism practice is considered free from ignorance when it reckons with the fact that spoken words are not neutral but are used to convey a broad sense of meaning that reflects the immediate social, political, and historical conditions of the speaker (Fiske, 1994). The analysis that follows examines how Nigerian journalists handled certain spoken words during the 2005 National Political Reform Conference in Nigeria.

\section{Methodology}

I selected three "typical texts" (Meyer, 2006: 18; Vandijk, 2006: 99 \& 101) from three leading national newspapers in Nigeria and presented the texts on a titled table. I designed a semi-structured questionnaire and used it to elicit comments from the editor of Punch newspaper. The questionnaire sought the editor's view on how I interpreted the texts I had selected from his newspaper for this research. The editor's view was audio recorded. Audio recording proceeded after the editor had voluntarily given his consent for such a procedure. In a similar vein, an e-mail was used to elicit a comment from the Vanguard newspaper's reporter who wrote the texts sampled from Vanguard newspaper. It should be stated that the use of a small purposively selected sample in this paper reflects the notion that sampling in qualitative research is best done with a small sample "purposively selected for its typicality as the best example that represents or reflects the other samples that were left out" (Maxwell, 1996: 71). Scholars agree also that anything such as a "oneword quotation or a lengthy story-like description can count as data" (Keyton, 2001: 70).

To ascertain journalists' degree of alertness to the notion that spoken words are not neutral, CDA was used for the interpretation and analysis of the sampled texts (Wodak \& Meyer, 2006). CDA is widely viewed as appropriate for describing, interpreting, analysing, and critiquing social life as reflected in texts (Luke, 1997). CDA has also been found useful for revealing discursive sources of power, dominance, and inequality (Van Dijk, 1988). When researchers use CDA, they "attribute a class of phenomena to segments of texts" (Fielding \& Lee, 1998: 41). In doing the attribution, I went further to triangulate the interpretation I gave to the texts with the comments elicited from the journalists who authored and/or disseminated the analysed texts.

Table 1: Literal Reporting of News Makers' Utterances 


\begin{tabular}{|l|l|l|l|}
\hline S/No & Newspaper & Exemplars & Date \\
\hline 1 & Punch & I'm not Obasanjo's spy (p.14) & $5 / 3 / 05$ \\
\hline 2 & Vanguard & $\begin{array}{l}\text { Obasanjo said the issue of funding had } \\
\text { been taken care of (p.14) }\end{array}$ & $16 / 2 / 05$ \\
\hline 3 & Guardian & $\begin{array}{l}\text { I don't cross a bridge until I reach it } \\
\text { (p.2) }\end{array}$ & $8 / 3 / 05$ \\
\hline
\end{tabular}

Source: Nigerian newspapers: Punch, Vanguard and Guardian of 2005

\section{Analytic interpretations}

Exemplar one in Table 1 was spoken by one of the delegates who was hand-picked by the then Nigerian President, Olusegun Obasanjo. The point to note here is that the declarative sentence constituting that exemplar does not only sound too categorical but makes excessive commitment to truth and transparency. Such excessive commitment to truth and transparency is known as "modal categorical claim to truth and knowledge" (Fairclough, 2001: 105 \& 2003: 170). Modal categorical claim to truth and knowledge as a discourse flaw manifests in contexts where a news source makes an unsubstantiated and excessive truth-commitment in a proposition. By virtue of such excessive truth-commitment, the journalist who reported the exemplar in the literal style as cited without getting worried by such high level of truth-commitment in that context, had by such act, exposed himself and his audience to the manipulative potentials that lurk in modal categorical claim to truth and knowledge.

This view derives from an outburst credited to President Obasanjo in the Punch, edition of 27 June 2005. The entailment of the outburst proves that when the delegate uttered exemplar one, his intention was really to hide the fact that he actually was Obasanjo's spy. In the said outburst, President Obasanjo had accused the chairman of the conference of being too economical with the details of the proceedings at the conference. In making the accusation, he had boasted that if not for the person who uttered exemplar one as cited in Table 1, that he, Obasanjo, would have been left in the dark regarding proceedings at the conference. Obasanjo's outburst demonstrated that the speaker of exemplar one succeeded in fooling the reporter when he tricked the reporter into reporting literally, that he was not Obasanjo’s spy. 
The point here is that the reporter succumbed to the manipulation of the speaker of exemplar one because the Nigerian journalism scholarship which produced the reporter disregards the qualitative research method in preference to the quantitative method. This disregard is rooted in the claim that human behaviour could be objectively observed and reported. When I asked the editor of Punch newspaper whether he was aware that disseminating exemplar one in the manner cited could be interpreted as helping the speaker to succeed in his bid to spy for President Obasanjo, a major part of his answer was:

No! We are only trying to expose him... he

said he was not a spy. But it's...now left to the public to judge him... it's now in...public court to decide. ...in Punch, we report as it is. We try to avoid imputations.

Source: transcribed interview with Punch Editor on 6 July 2007

The tenor of this answer vindicates Rosen's (1999) observation that journalists always invoke a public they hardly do enough to build. The answer is also tainted with the often over-rated ability of the audience to produce counter reading. This purported counterreading ability of the audience has, anyway, been found as marginal, insignificant, and ineffectual (Van Dijk, 2006; Condit, 1991).

The entailment of exemplar two, Table 1, provides yet another instance where wrong scholarship could be adjudged as undermining journalism practice. Upon realising that the entailment of exemplar two did not inform the audience properly regarding the source of funds for the conference, I contacted the reporter and asked him why he did not pressure the newsmaker to state precisely the source of funds for the conference. His reply was:

I do not think the readers' curiosity was sated by this story; clearly a lot could still have been done to 
enlighten the public. It was a story

with a shortcoming.

Source: e-mail response on May $30^{\text {th }} 2007$ from Vanguard newspaper reporter to the National Political Reform Conference

I attribute the shortcoming the reporter accepted to oversights that are traceable to the flaws of positivistic quantitative scholarship. This flaw rubs off on journalists whose training programme was exclusively informed by the quantitative research method. The quantitative method is considered flawed because it lacks dimensions capable of alerting student-journalists on the manipulative subtleties that lurk in both "the art of saying nothing" (Hahn, 1998:.105ff) and "restricted language code/variant" (Gouldner, 1976:105ff; Littlejohn, 1996: 197f; Gripsrud, 2002:32; Verschueren, 1999: 118 \& Griffin, 2000: 344). When summarised, "the art of saying nothing" and "restrictive language code" denote a stratagem drawn on by news makers when they want to make the audience overlook the fact that the real issue is being avoided (Hahn, 1998).

In a similar vein, it needs to be said that the oversight that prompted the dissemination of exemplar two by Vanguard newspaper, also induced the flaw in exemplar three, Table 1. Exemplar three was uttered in response to a question demanding what the news source would do to ensure that the recommendations of the political conference would not be swept under the carpet as had always been the fate of recommendations of similar conferences in Nigeria. The fact that the recommendations of the conference have been gathering dust in abandonment since July 2005 is more than enough evidence showing that the speaker of exemplar three got to the bridge and failed to cross it.

The point is that the journalist who raised the question that yielded exemplar three Table 1 ought to have known that the news source uttered the exemplar in order to avoid the question of what he would do to ensure that the recommendations of the conference would be implemented. The journalist's failure to reckon with the news source's ploy furnishes the premise to say that the journalist lacked the know-how which would have helped him to detect and contest the manipulation which exemplar three entails. And to this paper, 
such lack is a consequence of a quantitative mass media scholarship which fails to infuse critical skills to journalists during training.

\section{Closing remarks}

As the analysis has demonstrated, the comments elicited from interviewed journalists underscore why the current state of media research in Nigeria needs improvement. For instance, when the editor of Punch newspaper said "we try to avoid imputations in news coverage", he was drawing on a tacit quantitative research tradition that encourages journalists not to bother with the meaning of reported facts. Since the quantitative research method tends to over-value the validity of observable objective reality, there is hardly any surprise when journalists who are products of such media scholarship fail to reckon with imputations and subtle manipulations that undermine news production skills (Simpson, 1993; Fairclough, 2001).

When a media practice-tradition ignores the fact that "news generates tension as a result of the dissonance between information and the affect structure of news recipients" (Gouldner, 1976:112), such a practice-tradition cannot escape censure from segments of news audience. The need to eliminate such censure and infuse tension-reduction orientation in journalism practice imposes a demand for a mass communication research tradition capable of ensuring that media practice remains alert to subtle manipulations that come from news sources. This demand will be redeemed when mass communication research embraces the imperative of "turn to the critical" in social research (Hardt, 2004: 111). The need to embrace such an imperative in media research, resonates with Durham \& Kellner, when they stated:

In a post-modern media and computer culture, fresh critical strategies are needed to read cultural texts, to interpret the conjunctions of sight, sound, words and images that are producing seductive cultural spaces and experiences... we need to create a counter pedagogy to question and critically analyse the often distorted forms of knowledge, misinformation, 
deceptive images and seductive spectacle of media and consumer society (2001: 291).

A key way of embracing this much-needed, fresh, critical strategy is to encourage the interpretive tradition in mass communication research. This encouragement should seek a compromise that is capable of making the dominance of positivistic quantitative tradition in media research to recognise and submit to the resurgence of the interpretive qualitative tradition in social science research. Moving along this path will check the disingenuous exclusion of qualitative mass media research perspective in African mass communication scholarship (De Beer \& Tomaselli, 2000). In specific terms, what Nigeria and other African countries need is an action-plan to nudge national governments into realising the renaissance of qualitative social research. Governments in other parts of the world, through the establishment of national qualitative research centres, are now awakening to the need of giving qualitative research the attention it deserves (Henwood \& Lang, 2005; Shalva, 2005).

\section{About the author}

Dr. Fred Amadi is a Senior Lecturer on the departmental board of Mass Communication at the Rivers State University of Science and Technology, Port Harcourt, Nigeria. Dr. Amadi researches in the area of Hermeneutics and Critical Discourse Analysis and has published, among others, Letters to the editor as a parameter of examining agenda-setting theory in the Nigerian context; Rhetoric of presentation in Nigeria's social discourse.

Contact details: Department of Mass Communication, Rivers State University of Science \& Technology, PMB 5080, Nkpolu, Port Harcourt, Rivers State, Nigeria. Telephone: +23 47038087887. E-mail: dbaff2k4@yahoo.com

\section{References}

Ajala, V. (1996). Scholarly writing guide for researchers. Ibadan: MayBest Publishers.

Ang, I. (2001). On the politics of empirical audience research. In M. Durham \& D. Kellner (Eds), Media and cultural studies (pp. 177-197). Massachusetts: Blackwell Publishers Ltd.

Birkhead, D. (1991). An ethics of vision for journalism. In R. Avery \& D. Eason (Eds), Critical perspectives on media and society (pp. 226-239). New York: The Guilford Press. 
Branston, G. \& Stafford, R. (2007). The media student's book. London \& New York: Rutledge.

Carew, J. (1996). Mass communication as cultural process. In J .Hanson, \& D. Maxcy (Eds), Sources notable selections in mass media (pp.233-242). Connecticut: Time's Higher Education Group Company.

Condit, C. (1991). The rhetorical limits of polysemy. In R. Avery \& D. Eason, (Eds), Critical perspectives on media and society (pp.365-386). New York: The Guilford Press.

Cresswell, J.W. (2007). Qualitative inquiry \& research design. London: Sage publications.

De Beer, A. \& Tomaselli, K. (2000). South African journalism and mass communication scholarship: negotiating ideological schisms. Journalism studies, 1 (1): 933.

Dennis, E. (1989) ). Reshaping the media. California: Sage Publications.

Durham, M. \& Kellner, D. (2001). Media and cultural studies. Massachusetts: Blackwell Publishers Ltd.

Eliasoph, N. (1997). Routines and the making of oppositional news. In D. Berkowitz (Ed), Social meanings of news (pp. 230-254). London: Sage Publications.

Fairclough, N. (2001). Language and power. London: Longman.

Fairclough, N. (2003). Analysing discourse: textual analysis for social research. London: Rutledge.

Fiske, J. (2004). Opening the hallway: some remarks on the fertility of Stuart Hall's contribution to critical theory. In D. Morley \& K. Chen (Eds), Critical dialogues in cultural studies (pp.212-220). London: Rutledge.

Fiske, J. (1994). Media matters: everyday culture and political change. Minneapolis: University of Minnesota Press.

Gobo, G. (2005). The renaissance of qualitative methods. Forum qualitative social research fqs 6(3). Art 42. Retrieved 28 May 2007 from the World Wide Web: http//www.qualitative-research.net/fqs/

Gouldner, A. (1976). The dialectics of ideology and technology. London: Macmillan Press Ltd.

Griffin, E. (2000). A first look at communication theory. New York: McGraw Hill.

Gripsrud, J. (2002). Understanding media culture. London: Arnold. 
Hahn, D. (1998). Political communication. Pennsylvania: Strata Publishing INC.

Hardt, H. (2004). British cultural studies and the return of the critical in American mass communication research: accommodation or radical change? In D. Morley, and K. Chen (Eds), Critical dialogue in cultural studies (pp. 102-111). London: Rutledge.

Henwood, K. \& Lang, I. (2005). Qualitative social science in the UK: a reflexive commentary on the "state of the art". Forum Qualitative Sozialforschung / Forum :Qualitative Social Research, 6(3), Art. 48. Retrieved 6 June 2009 from the World Wide Web: http://nbn-resolving.de/urn:nbn:de:0114-fqs0503486

Keyton, J. (2001). Communication research. New York: McGraw Hill.

Kunczik, M. (1995). Concepts of journalism north and south. Bonn: Friedrich Ebert Foundation.

Lanigan, R. (1988). Phenomenology of communication. Pittsburgh, PA: Duquesne University Press.

Lindlof, T. \& Taylor, B. (2002). Qualitative communication research methods. London: Sage Publications.

Littlejohn, S. (1996). Theories of human communication. Toronto: Wadsworth Publishing Company.

Luke, A. (1997). Theory and practice in critical science discourse. In L. Saha, (Ed), International encyclopedia of the sociology of education. Accessed 19 March 2008 from the World Wide Web: http://www.gseis.ucla.edu/courses/ed253a/Luke/SAHA6.html

Maxwell, J. (1996). Qualitative research design: an interactive approach. London: Sage Publications.

Mayhew, L. (1997). The new publics. London: Cambridge University Press.

Meyer, M. ( 2006). Between theory, method and politics: positioning of the approaches to CDA. In R. Wodak \& M. Meyer ( Eds), Methods of critical discourse analysis (pp.14-31). London: Sage Publications Ltd.

National Open University Of Nigeria (2009). Retrieved 2 December 2009 from the World Wide Web: www.nounonline.com

Okeke, C. \& Ume, T. (2004). Some epistemological issues in the conduct of social and behavioural studies in the faculty of education of Nigeria universities. The Qualitative Report, 9 (2) June, 2004. Retrieved 18 August 2007 from the World Wide Web: http://www.nova.edu/ssss/QR/QR9-2/okeke.pdf

Pyrczak, F. \& Bruce, R. (2005). Writing empirical research reports. Glendale: Pyrczak Publishing. 
Olumhense, S. (2005). Journalism wrestles graft. The Guardian, 24 April 2005: 37.

Reese, S. (1997). The news paradigm and the ideology of objectivity: A socialist at the Wall Street Journal. In D .Berkowitz (Ed), Social meanings of news (pp.220-240).

London: Sage Publications.

Reinard, J. (1994). Communication research. Wisconsin: WCB Brown \& Benchmark Publishers.

Ritzer, G. (2000). Modern sociological theory. New York: McGraw-Hill Higher Education.

Rosen, J. (1999). What are journalists for? London: Yale University Press.

Schiller, H. (1996). Mass media, power and ideology. In J .Hanson, \& D. Maxcy (Eds), Sources notable selections in mass media (pp.171-179). Connecticut: Time's Higher Education Group Company.

Seganti, F. R. (2010). Practicing reflexivity in the study of Italian migrants in London. The Qualitative Report, 15(4), 966-987. Retrieved 2 November 2010 from the World Wide Web; http://www.nova.edu/ssss/QR/QR15-4/seganti.pdf

Shalva, W. (2005). Qualitative methods in Israel. Forum qualitative socialforschung/forum: qualitative social research, 6(3), Art. 46. Retrieved 6 June 2009 from the World Wide web; http://www. quantitativeresearch.net/index.php/fqs/article/view/9/20

Silverman, D. \& Marvasti, A. (2008). Doing qualitative research: a comprehensive guide. London: Sage Publications.

Silverman, D. (2006). Interpreting qualitative data. London: Sage Publications. Simpson, P. (1993). Language, ideology and point of view. London: Rutledge.

Swanson, D. (2011). World Wide Web sites and social order within higher education journalism and mass communication programmes. Retrieved 16 July 2011 from the World Wide Web: http://www.calpoly.edu/-dswanson/intro.htm

Tinubu, B. (2005).Media reform and the challenge of development. Guardian, 24 April 2005: 65 .

Tucker, K. (1998). Anthony Giddens and modern social theory. London: Sage Publications.

Udoakah, N. (1993). The anatomy of mass communication message. Journal of Humanities, 3(1).

Van Dijk, T. (2006). Discourse and Manipulation. Article 354. Discourse \& Society. 17(2):359-383. Retrieved 22 October 2008 from the World Wide Web: http://das.sagepub.com 
Van Dijk, T. (2006). Multidisciplinary CDA: a plea for diversity. In R. Wodak, \& M. Meyer (Eds), Methods of critical discourse analysis (pp.95-120). London: Sage Publications Ltd.

Van Dijk, T. (1988). News as discourse. Hillside, NJ: Erlbaum.

Verschueren, J. (1999). Understanding pragmatics. London: Arnold.

Wikipedia.org (2011). Retrieved 17 July 2011 from the World Wide Web: http://www.en.wikipedia.org/wiki/journalismschool

Wodak, R. \& Meyer, M. (Eds), Methods of critical discourse analysis. London: Sage Publications Ltd. 